\title{
Knowledge and attitudes of infertile couples towards embryo donation program
}

\author{
Usha Rajinikanthan D. B.*
}

\begin{abstract}
Fellowship in Reproductive Medicine, Institute of Reproductive Medicine and Women's Health, Madras Medical
\end{abstract} Mission, Chennai, India

Received: 04 November 2015

Revised: 05 November 2015

Accepted: 15 December 2015

\section{*Correspondence:}

Dr. Usha Rajinikanthan D.B.,

E-mail: Usha_jipmer@yahoo.co.in

Copyright: ( $\odot$ the author(s), publisher and licensee Medip Academy. This is an open-access article distributed under the terms of the Creative Commons Attribution Non-Commercial License, which permits unrestricted non-commercial use, distribution, and reproduction in any medium, provided the original work is properly cited.

\begin{abstract}
Background: Despite a high population growth rate in India, infertility remains as a major reproductive health problem. Although, a large number of infertile couples have already benefited from assisted reproductive technology (ART), some have remained childless. One possible option that they may consider is embryo donation (ED) procedure. There are still worldwide controversial attitudes regarding ED program. The aim of this study is to evaluate the attitudes and knowledge of infertile couples on different aspects of embryo donation program.

Methods: A total of 200 infertile patients (women, $n=101$; men, $n=99$ ) attending our clinic, were asked to fill out the questionnaires. Part I of the questionnaire form contained general demographic information. Part II contained 14 questions to reveal their knowledge and attitudes about ED program.

Results: The vast majority of the subjects had formal education. Nearly $80 \%$ were in favor of embryo donation program for selected infertile couple. Psychological counseling was strongly recommended by vast majority of respondents for both donor and the recipient of the embryos. Majority of the participants were in favor of ED over adopting a child.

Conclusions: The vast majority of infertile patients had positive attitudes toward ED as treatment for selected infertile cases.
\end{abstract}

Keywords: Knowledge, Attitude, Embryo donation

\section{INTRODUCTION}

Approximately one-third of all assisted reproductive technology-treated couples have surplus embryos of good quality following embryo transfer. These surplus embryos are usually cryopreserved for subsequent treatment cycles and are normally utilized by the couples. However, a fraction of the embryos are either left unattended, or reach a legislative maximum storage period without being used for treatment. ${ }^{1}$

The right candidates for embryo donation (ED) are also women with no/or poor quality oocytes, premature ovarian failure, gonadal dysgenesis or ovarian failure due to chemo/ radiotherapy, recurrent IVF failure, genetic diseases and women whose partners have severe male infertility. ${ }^{2}$ Also, unlike adoption, the couple does not have to go through a legal process in order to be declared the child's legal parents.,

Embryo donation is an accepted method in assisted reproduction techniques in many parts of the world. Therefore, the aim of this descriptive survey was to investigate the attitudes of infertile couples towards different aspects of ED. 


\section{METHODS}

This descriptive study was undertaken at Institute of Reproductive Medicine (IRM) in Madras Medical Mission, Chennai.

A total of 200 infertile patients (women, $\mathrm{n}=101$; men, $\mathrm{n}=99$ ) attending our clinic, were asked to fill out the questionnaires. The questionnaire form consisted of two parts, part I contained questions to determine the demographic characteristics of all infertile participants and part II consisted of 14 multiple choice questions to reveal both knowledge and attitudes of respondents about application of ED program. The participants were given the choice to choose only one answer- "Yes", "No", "Do not know".

\section{RESULTS}

The vast majority of the subjects had formal education. The majority belonged to the age group of 18-39, which represents the population of reproductive age.

Table 1: Observation table.

\begin{tabular}{|c|c|c|c|c|}
\hline Question & Answer & Women & Men & Percentage (\%) \\
\hline \multirow{3}{*}{$\begin{array}{l}\text { 1. Do you support the embryo donation program } \\
\text { for selected infertile couples? }\end{array}$} & Yes & 80 & 81 & 80.5 \\
\hline & No & 11 & 12 & 11.5 \\
\hline & Don’t know & 10 & 06 & 08 \\
\hline \multirow{3}{*}{$\begin{array}{l}\text { 2. If you would remain childless, do you think that } \\
\text { it would have an impact on your relationship with } \\
\text { your spouse? }\end{array}$} & Yes & 39 & 24 & 31.5 \\
\hline & No & 73 & 51 & 62 \\
\hline & Don't know & 08 & 05 & 6.5 \\
\hline \multirow{3}{*}{$\begin{array}{l}\text { 3. If you had an embryo donation child, } \\
\text { Would you like to share the message with your } \\
\text { friends and relatives? }\end{array}$} & Yes & 18 & 22 & 20 \\
\hline & No & 77 & 71 & 74 \\
\hline & Don’t know & 06 & 06 & 06 \\
\hline \multirow{3}{*}{$\begin{array}{l}\text { 4. Do you think that it is possible for the couple to } \\
\text { love and care for an embryo donation child as } \\
\text { much as a genetic child? }\end{array}$} & Yes & 82 & 80 & 81 \\
\hline & No & 05 & 06 & 5.5 \\
\hline & Don't know & 14 & 13 & 13.5 \\
\hline \multirow{3}{*}{$\begin{array}{l}\text { 5. If you have surplus number of cryo-preserved } \\
\text { embryos, would you prefer to donate to these } \\
\text { couples? }\end{array}$} & Yes & 79 & 73 & 76 \\
\hline & No & 13 & 13 & 13 \\
\hline & Don’t know & 09 & 13 & 11 \\
\hline \multirow{3}{*}{$\begin{array}{l}\text { 6. Would your religion accept Embryo donation } \\
\text { for infertility treatment? }\end{array}$} & Yes & 47 & 44 & 45.5 \\
\hline & No & 12 & 08 & 10 \\
\hline & Don't know & 42 & 47 & 44.5 \\
\hline \multirow{3}{*}{$\begin{array}{l}\text { 7. Is it necessary to have independent } \\
\text { psychological counseling for both recipient and } \\
\text { embryo donor? }\end{array}$} & Yes & 70 & 74 & 72 \\
\hline & No & 17 & 12 & 14.5 \\
\hline & Don't know & 13 & 14 & 13.5 \\
\hline \multirow{3}{*}{$\begin{array}{l}\text { 8. If people need embryo transfer, the treatment } \\
\text { should be kept confidential between the couples } \\
\text { and their physician? }\end{array}$} & Yes & 91 & 90 & 90.5 \\
\hline & No & 04 & 05 & 04.5 \\
\hline & Don’t know & 06 & 04 & 05 \\
\hline \multirow{3}{*}{$\begin{array}{l}\text { 9. A child should never know that he/she is born } \\
\text { from embryo donation. }\end{array}$} & Yes & 81 & 74 & 77.5 \\
\hline & No & 15 & 18 & 16.5 \\
\hline & Don’t know & 06 & 06 & 06 \\
\hline \multirow{3}{*}{$\begin{array}{l}\text { 10. Should there be any age restriction for recipient } \\
\text { of embryo? }\end{array}$} & Yes & 29 & 33 & 31 \\
\hline & No & 34 & 32 & 33 \\
\hline & Don't know & 38 & 34 & 36 \\
\hline \multirow{3}{*}{$\begin{array}{l}\text { 11. Do you think that embryo donation is better } \\
\text { than adoption? }\end{array}$} & Yes & 80 & 76 & 78 \\
\hline & No & 08 & 14 & 12 \\
\hline & Don't know & 12 & 10 & 11 \\
\hline \multirow{3}{*}{$\begin{array}{l}\text { 12. Are the recipients concerned about whether a } \\
\text { donor may try to find the baby and claim it? }\end{array}$} & Yes & 26 & 34 & 30 \\
\hline & No & 52 & 40 & 46 \\
\hline & Don't know & 23 & 25 & 24 \\
\hline \multirow{3}{*}{$\begin{array}{l}\text { 13. Do you think that recipient of embryo should } \\
\text { know the identifying information of the embryo } \\
\text { donor? }\end{array}$} & Yes & 17 & 17 & 17 \\
\hline & No & 72 & 71 & 71.5 \\
\hline & Don't know & 12 & 11 & 11.5 \\
\hline \multirow{3}{*}{$\begin{array}{l}\text { 14. Do you know the other causes for embryo } \\
\text { donation like hereditary disorder etc.? }\end{array}$} & Yes & 19 & 14 & 16.5 \\
\hline & No & 23 & 24 & 23.5 \\
\hline & Don’t know & 59 & 61 & 60 \\
\hline
\end{tabular}


Table 2: Demographic characteristics of the infertile participant.

\begin{tabular}{|lll|}
\hline $\begin{array}{l}\text { Characteristics } \\
\text { Educational level }\end{array}$ & $\begin{array}{l}\text { Women } \\
(\mathrm{n}=101)\end{array}$ & Men $(\mathbf{n = 9 9})$ \\
\hline School & 18 & 17 \\
\hline University & 83 & 82 \\
\hline Religion & & \\
\hline Hindu & 90 & 88 \\
\hline Muslim & 8 & 7 \\
\hline Christian & 3 & 3 \\
\hline Age group & & \\
\hline 19-29 years & 34 & 9 \\
\hline 30-35 years & 47 & 33 \\
\hline 36-40 years & 15 & 35 \\
\hline$>40$ years & 5 & 22 \\
\hline
\end{tabular}

\section{DISCUSSION}

The practice of ED involves religious, ethical, social, and psychological issues. Different aspect of ED program such as, knowledge of general public or infertile patients, known and anonymous donors, age limits for donors and recipients, secrecy or disclosure to the children of ED have been debated since the introduction of $\mathrm{ED} .^{5}$

The results generated from this study showed that the majority of infertile couples (80\%), with different educational background, support ED as an alternative way of overcoming infertility, a finding in line with the results of Isikoglu et al. ${ }^{7}$ The positive attitudes towards ED may be due to the fact that it implies a biological link between the offspring and both parents. Although, the recipient is not genetically linked, she will enjoy carrying the fetus biologically, and takes care of the nursing. This shows that people, in general, give the priority of having a full family with children. ${ }^{5}$

In family based culture, such as ours, infertility is considered as a major public problem, which may affect the spouse relationships or even threat their marriage. This stressful situation becomes even more serious when the wife is encountered with infertility8. In our study $62 \%$ of the couple declined that remaining childless will not affect their relationship. Certainly this level of understanding can be correlated with the level of education and about $80 \%$ of our respondents had graduate degree.

Most of the participants (74\%) claimed that if they had a child by ED, they would never tell their friends or family members about it. Also, only a limited number of the subjects thought that although genetics play some role in what we are, but the way we are brought up was more important. In addition, nearly $80 \%$ of participating men and women thought that couples can love their child resulted from ED as much as a genetic child.
The patient willingness to donate surplus cryo preserved embryos is highly dependent on the aim of donation, and generally, patients seem more reluctant to donate for infertility treatment compared to donation for research. ${ }^{1}$ More than half of the couples in the present investigation were open to the idea of embryo donation for infertility $(76 \%)$.

As for as religious issues are concerned, near half of the patients $(44.5 \%)$ were unaware that their religion would permit ED or not.

The purpose of the counseling is to assess the psychological readiness of the couple to undergo ED and to help the couple anticipate the short and long term social, psychological, and ethical implications of ED. ${ }^{9}$ The American Society for Reproductive Medicine (ASRM) guidelines for ED recommended comprehensive psychological assessment for donors as well as recipients of embryos. ${ }^{6}$ This is to ensure that they will be fully aware of all relevant aspects of the assisted reproduction with ED. The majority of our respondents (72\%) believed that psychological counseling is necessary for both embryo donor as well as recipient. Counseling offered to recipients are to make sure they are giving informed consent, are aware of the medical and the psychological risks involved, and understand the ethical and emotional issues involved in creating families through the process of ED. ${ }^{5}$

The majority (90.5\%) believed that only couples and their physicians should be aware of ED treatment. Another important issue to point out is disclosure or nondisclosure to the children of ED treatment. The parents are usually confused about when and how to tell the child about his/ her origin. ${ }^{10}$ Nearly (77\%) of our respondents believed that the children should not be aware of their origin. Finally, they believe that their child has the right to know about his/ her genetic origins for medical as well as psychological reasons. ${ }^{11}$ Whereas most countries, such as ours, continue to support the anonymous donation, children have the right to receive information about the donor.

Another controversial issue is related to the age of the embryo recipients. Among the respondents in our survey, the majority stated that there should be an age restriction for recipient of embryos. It seems that general public feels that it is not fair to children to be raised by parents who look and probably act much like grandparents. As a result, our respondents considered an age limit for recipients in ED program.

Majority of them (71.5\%) believed that recipient should not know the name and address of embryo donor. Sometimes, the recipients have worries about the donors. One concern is that she will not be able to separate emotionally from her embryos and that as pregnancy progresses, the growing fetus will feel like her own child. ${ }^{1}$ Our data indicated that $46 \%$ of our respondents 
believed that the donors did not have the right to claim the offspring, which is in line with previous report.

Adoption refers to a specific legal procedure that establishes or transfers parentage of existing children. ${ }^{6}$ Nearly $80 \%$ of the couple believed that embryo donation is better option compared to adoption.

\section{CONCLUSIONS}

In conclusion, embryo donation represents a useful option for couples with otherwise untreatable infertility of both partners to fulfil their family building goals. However, moral and ethical issues regarding third party reproduction as well as acceptance of these options by both society and patients should be addressed fully. Since, the majority of participants were unaware of their religious opinion regarding ED; more discussion should be stimulated among them. Also, the mass media should play more active role in informing the public about the ED in assisted reproduction.

\section{ACKNOWLEDGEMENTS}

The authors would like to thank the participants for their sincere cooperation during the course of this survey.

Funding: No funding sources

Conflict of interest: None declared

Ethical approval: Not required

\section{REFERENCES}

1. Bangsboll S, Pinborg A, Yding AC, Nyboe AA. Patients' attitudes towards donation of surplus cryopreserved embryos for treatment or research. Hum Reprod. 2004;19:2415-9.

2. Lee J, Yap C. Embryo donation: a review. Acta Obstet Gynecol Scand. 2003;82(11):991-6.

3. Soderstrom-Anttila V, Foudila T, Ripatti UR, Siegberg R. Embryo donation: outcome and attitudes among embryo donors and recipients. Hum Reprod. 2001;16:1120-8.

4. Kovacs GT, Breheny SA, Dear MJ. Embryo donation at an Australian university in-vitro fertilization clinic: issues and outcomes. Med J Aust. 2003;178:127-9.

5. Ghasemi N, Khalili MA, Tayyebi N. Knowledge and attitudes of infertile couples towards embryo donation program: a preliminary report from Iran

6. The American Society for Reproductive Medicine. Guidelines for embryo donation in 2004. Fertil Steril. 2004;82.

7. Isikoglu M, Senol Y, Berkkanoglu M, Ozgur K, Donmez L, Stones-Abbasi A. Public opinion regarding oocyte donation in Turkey: first data from a secular population among the Islamic world. Hum Reprod. 2006;21:318-23.

8. Yassini M, Khalili MA, Hashemian Z. The level of anxiety and depression among Iranian infertile couples undergoing in vitro fertilization or intracyto plasmic sperm injection cycles. J Research in Med Sci. 2005;10:22-6.

9. Newton CR, McDermid A, Tekpetey E, Tummon IS. Embryo donation: attitudes toward donation procedures and factors predicting willingness to donate. Hum Reprod. 2003;18:878-4.

10. Marcu SF, Marcus NK. Embryo donation. Assist Reprod. 1999;9:138-43.

11. Van Voorhis BJ, Grinstead DM, Sparks AET. Establishment of a successful donor embryo program: medical, ethical, and policy issues. Fertil Steril. 1999;71:604-8.

Cite this article as: Rajinikanthan DBU. Knowledge and attitudes of infertile couples towards embryo donation program. Int J Reprod Contracept Obstet Gynecol 2016;5:323-6. 